\title{
Surface Energy Balance Measurements Above an Exurban Residential Neighbourhood of Kansas City, Missouri
}

\author{
Ahmed A. Balogun • Jimmy O. Adegoke • \\ Sajith Vezhapparambu - Matthias Mauder • \\ Joseph P. McFadden • Kevin Gallo
}

Received: 1 December 2008 / Accepted: 13 August 2009 / Published online: 29 August 2009

(C) The Author(s) 2009. This article is published with open access at Springerlink.com

\begin{abstract}
Previous measurements of urban energy balances generally have been limited to densely built, central city sites and older suburban locations with mature tree canopies that are higher than the height of the buildings. In contrast, few data are available for the extensive, open vegetated types typical of low-density residential areas that have been newly converted from rural land use. We made direct measurements of surface energy fluxes using the eddy-covariance technique at Greenwood, a recently developed exurban neighbourhood near Kansas City, Missouri, USA, during an intensive field campaign in August 2004. Energy partitioning was dominated by the latent heat flux under both cloudy and near clear-sky conditions. The mean daytime Bowen ratio $(\beta)$ values were $0.46,0.48$, and 0.47 respectively for the cloudy, near clear-sky and all-sky conditions. Net radiation $\left(R_{n}\right)$ increased rapidly from dawn $\left(-34\right.$ and $\left.-58 \mathrm{~W} \mathrm{~m}^{-2}\right)$ during the night to reach a maximum $\left(423\right.$ and $\left.630 \mathrm{~W} \mathrm{~m}^{-2}\right)$ after midday for cloudy and near clear-sky conditions respectively. Mean daytime values
\end{abstract}

This research was conducted while the first author was a postdoctoral associate at the University of Missouri Kansas City.

\footnotetext{
A. A. Balogun $(\bowtie)$

Department of Meteorology, Federal University of Technology, Akure, PMB 704, Akure, Ondo State, Nigeria

e-mail: abalogun99@yahoo.com

J. O. Adegoke $\cdot$ S. Vezhapparambu

Laboratory for Climate Analysis and Modelling, Department of Geosciences,

University of Missouri-Kansas City, Kansas City, MO 64110, USA
}

\section{Mauder}

Institute for Meteorology and Climate Research, Atmospheric Environmental Research, Karlsruhe Institute of Technology, Kreuzeckbahnstraße 19, 82467 Garmisch-Partenkirchen, Germany

J. P. McFadden

Department of Geography, University of California, Santa Barbara, CA 93106-4060, USA

K. Gallo

NOAA/NESDIS Office of Research and Applications, Camp Springs, MD, USA 
were 253 and $370 \mathrm{~W} \mathrm{~m}^{-2}$, respectively for the cloudy and near clear-sky conditions, while mean daily values were 114 for cloudy and $171 \mathrm{~W} \mathrm{~m}^{-2}$ for near clear-sky conditions, respectively. Midday surface albedo values were 0.25 and 0.24 for the cloudy and near clear-sky conditions, respectively. The site exhibited an angular dependence on the solar elevation angle, in contrast to previous observations over urban and suburban areas, but similar to vegetated surfaces. The latent heat flux $\left(Q_{E}\right)$, sensible heat flux $\left(Q_{H}\right)$, and the residual heat storage $\Delta Q_{s}$ terms accounted for between $46-58 \%, 21-23 \%$, and $18-31 \%$ of $R_{n}$, respectively, for all-sky conditions and time averages. The observed albedo, $R_{n}$, and $Q_{E}$ values are higher than the values that have been reported for suburban areas with high summer evapotranspiration rates in North America. These results suggest that the rapidly growing residential areas at the exurban fringe of large metropolitan areas have a surface energy balance that is more similar to the rural areas from which they were developed than it is to the older suburbs and city centres that make up the urban fabric to which they are being joined.

Keywords Bowen ratio - Eddy covariance $\cdot$ Evapotranspiration $\cdot$ Heat fluxes · Radiation fluxes · Urban surface energy balance

\section{Introduction}

Rapid urbanization is a prime example of a human-induced phenomenon that can have significant impacts on people, the environment, and regional resources. As cities grow, urban sprawl creates unique challenges related to land-use planning, ecological structure and pollution, biodiversity, water, nutrient, and energy flows within cities and their surrounding areas. Changing land use and land cover in and around major metropolitan areas due to urban development is now recognized as a major factor leading to distinct urban climates. These urban climate effects are due to differences in the exchange of heat, mass, and momentum between the city and its pre-existing landscape. Thus the understanding, prediction, and mitigation of urban climate effects are intricately tied to the knowledge of surface-atmosphere interactions in urban environments (Grimmond et al. 2004a). Over the last century in the United States heat waves and elevated concentrations of ambient pollutants have been recognized as major public health issues in large metropolitan areas and evidence is mounting that human influence significantly increases the frequency and intensity of heat waves (Stott et al. 2004; Meehl and Tebaldi 2004). To effectively assess current and future potential public health risks due to heat and air quality changes driven by climate and land-use changes, integrated assessment methods that combine field measurements with sophisticated computational and modelling systems are required (Dabberdt et al. 2004). These models must accurately represent surface forcing across the observed range of weather conditions and urbanized surface types (broadly categorized as downtown, commercial, industrial, suburban, and exurban). Each category has distinct morphological characteristics that can be defined by the amounts and types of vegetation, buildings and impervious materials, roughness element height and density, and other factors (Oke 2004). This diversity results in varying degrees of controls on flux partitioning between the urban surface and atmosphere across a metropolitan area and the development of distinct microscale to local-scale climates (Oke 1997). The recognition of these has motivated research to understand the spatial and temporal variability of surfaceatmosphere exchanges within and between land uses and the causes for these differences (Grimmond et al. 2004a).

Several studies have been conducted in North American cities (see Grimmond and Oke 2002 for a summary). Recent urban energy balance observations have also been conducted in 
other parts of the world, including Basel in Switzerland (Rotach et al. 2005), Lódź in Poland (Offerle et al. 2005a), Edinburgh in Scotland (Nemitz et al. 2002), Christchurch in New Zealand (Spronken-Smith 2002), Tokyo in Japan (Moriwaki and Kanda 2004), Marseille in France (Mestayer et al. 2004; Grimmond et al. 2004b) and the west African Sahel: Ouagadougou in Burkina Faso (Offerle et al. 2005b). Together, these studies document the temporal and spatial variability of energy flux partitioning in more densely built-up, old suburban residential locations with mature, tall tree canopies that are generally higher than the buildings and in downtown areas or central city sites (densely built-up area, low vegetation cover, tall buildings with massive walls and deep street canyons). However, data remain limited for the newer extensive, open residential landscapes that are typical of areas that are being rapidly converted from rural land use at the exurban fringe of most large metropolitan areas in North America. Here, we report on energy balance measurements over a new exurban residential area near Kansas City, Missouri during an intensive observation period in August 2004. This study is part of a larger programme to improve the representation of urban and rural land-use transitions in regional climate models (Adegoke et al. 2007; Carleton et al. 2008). The primary goal of the intensive field study was to determine whether the surface energy partition in the rapidly growing exurban residential land-use types could be parameterized in regional climate models similarly to the suburban surface types for which values are known from previous field campaigns in diverse urban regions.

\section{Methods}

\subsection{Metropolitan Area and Study Site}

Kansas City $\left(39^{\circ} 062003 \mathrm{~N}, 9^{\circ} 3526.723 \mathrm{~W}\right.$, elevation $\left.231 \mathrm{~m}\right)$ is situated at the confluence of the Kansas and Missouri Rivers, straddling the state border between Missouri and Kansas (Fig. 1). The city covers a total area of $824 \mathrm{~km}^{2}$ and had a population of 441,545 in 2000 (U.S. Census Bureau). Greenwood ( $38^{\circ} 51^{\prime} 3^{\prime \prime}$ N, $94^{\circ} 20^{\prime} 47^{\prime \prime} \mathrm{W}$ ) is located on the exurban fringe of the Kansas City metropolitan area in Jackson County, Missouri. Greenwood covers an area of $11 \mathrm{~km}^{2}$ and had a population of 3,952 in 2000 (U.S. Census Bureau). Typical of many exurban areas of the Kansas City metropolitan area, Greenwood has undergone rapid growth with several low-density residential housing developments that have been converted from rural land use within the last decade. The new exurban developments have extensive grass lawns and young trees that are generally lower than the height of the buildings.

The characteristics of the surface morphology of the Greenwood site were assessed by aerial photographs and field surveys. The surveys were conducted within a radius of approximately $500 \mathrm{~m}$ in all directions from our measurement tower, which was located in a $2 \times 2 \mathrm{~km}^{2}$ residential area (Fig. 1). The fractional land cover of the site is approximately $58 \%$ pervious (vegetated), 12\% impervious ground such as roads, sidewalks (pavements), parking lots and driveways, and $29 \%$ buildings (Table 1 ). Because it was recently developed, the neighbourhood has a much higher percentage of grass cover than is typical of North American suburban areas, which range from 7 to 35\% grass cover (Grimmond and Oke 2002).

\subsection{Measurements and Data Analysis}

The study was conducted during an intensive observation period from August 1 to 17, 2004; day of year (DOY) 213 to 230. We obtained permission from property owners to erect a $33 \mathrm{~m}$ telescoping tower in the backyard of a house in the middle of the neighbourhood for a 


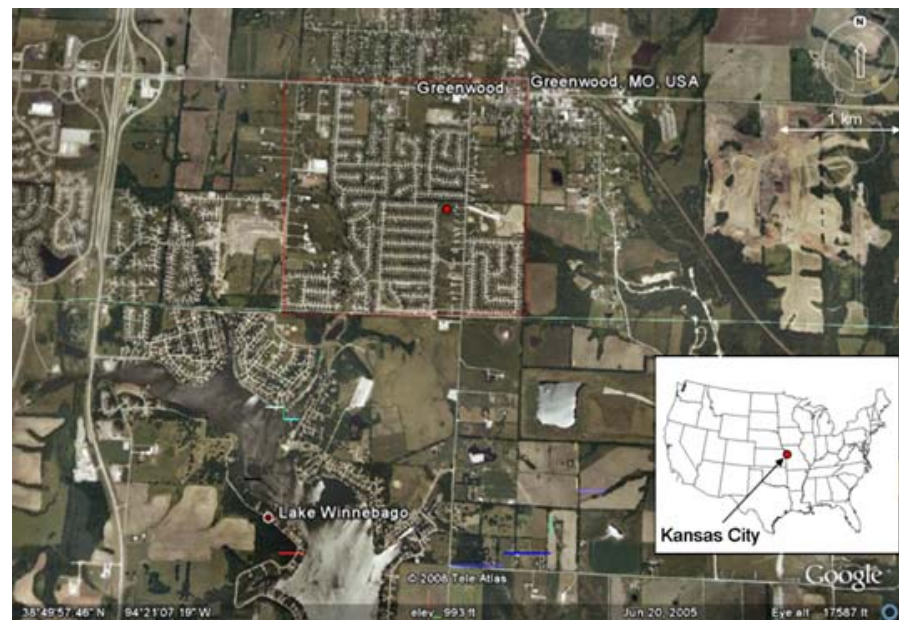

Fig. 1 Aerial imagery of the Greenwood, Kansas City suburban site including the area of interest (red square) and location of the measurement tower (red dot). Inset is the location of Kansas City in the USA. Source: Google Earth ${ }^{(}$

Table 1 Surface characteristics at the study site

a Estimated following Grimmond and Oke (1999a)

\begin{tabular}{ll}
\hline Surface property & Value \\
\hline Land use & Residential suburban \\
Buildings (\%) & 29.5 \\
Grass lawns (\%) & 50 \\
Trees and shrubs (\%) & 8 \\
Impervious (\%) & 12 \\
Water & 0.5 \\
Total built $(\%)$ & 42 \\
Total vegetated $(\%)$ & 58 \\
Roughness length, $z_{\mathrm{O}}(\mathrm{m})$ & $0.7^{\mathrm{a}}$ \\
Zero-plane displacement length, $z_{\mathrm{d}}(\mathrm{m})$ & $4.8^{\mathrm{a}}$ \\
Mean building height, $z_{H}(\mathrm{~m})$ & 6.9 \\
\hline
\end{tabular}

one-month period in the summer. We chose the intensive observational period approach because it allowed us to access a difficult location that provided a large, relatively homogeneous fetch within a new residential development. A similar, field campaign approach was employed in many of the previous studies (Roth and Oke 1993; Grimmond and Oke 1995, 1999c; Oke et al. 1999) on which key parameters of suburban land-surface types have been determined. Observations were taken from a 33-m high instrumented tower located in the backyard of one of the houses in a new residential area of predominantly single-family, detached dwellings of 1-2 storeys, with extensive luxuriant grass lawns and one to two young trees in front of and behind the houses. The trees are typically lower in height compared to the houses, with a few shooting just above or at about the same level as the roof of the houses. The neighbourhood consists of rows of houses running along straight east-west and north-south oriented streets, spaced about 35-50 m apart, each covering an area of 12-15 m in length 


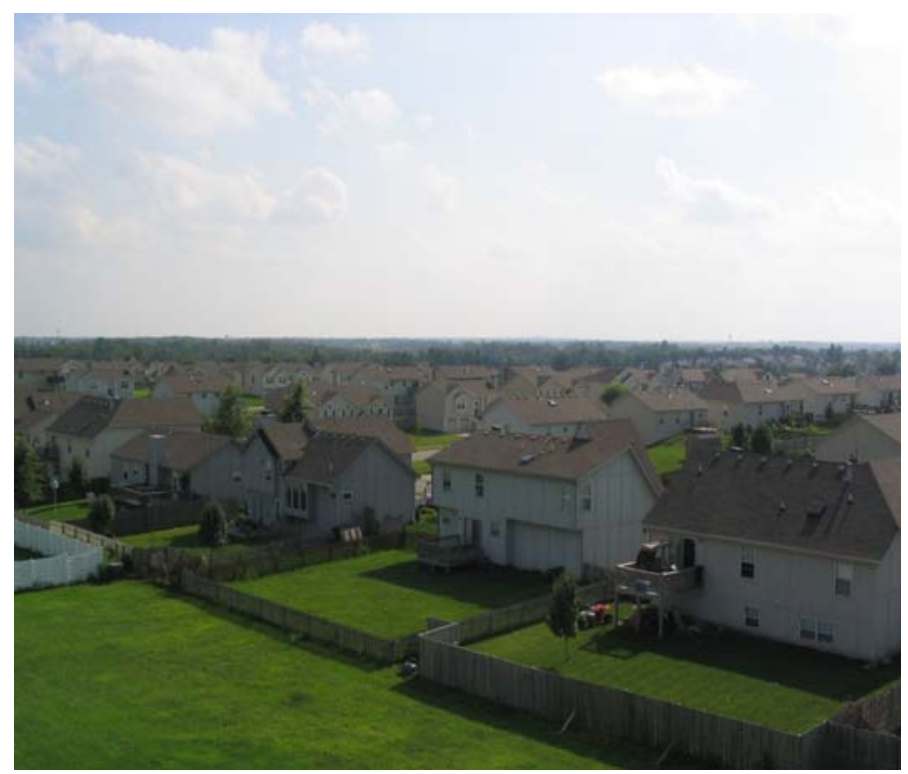

Fig. 2 View of the study site to the south-west from the measurement tower

and $15-18 \mathrm{~m}$ in breadth. The houses were typically made of concrete bases, wooden frames and walls, black and grey tiled roofs, and painted with various shades of bright colours. The Greenwood site is representative of Urban Climate Zone type 5 in the recent simplified classification of urban forms (Oke 2004). The tower was surrounded by grass lawns to the north and south, and rows of building to the east and west within a distance of about $60 \mathrm{~m}$ (Fig. 2). The mean height of the buildings $\left(z_{\mathrm{Hb}}\right)$ was $6.9 \mathrm{~m}$ and the mean height of the trees was $5.8 \mathrm{~m}$, giving an approximate roughness length and zero-plane displacement of 0.69 and $4.83 \mathrm{~m}$ respectively, based on rule-of-thumb estimates (Grimmond and Oke 1999a).

The instrument tower was a guyed, triple-axle nested mobile telescoping mast (U.S. Tower Corporation model MTU-07MDPLHD), with a 2.0-m extension (making our measurement height, $z_{m}, 35 \mathrm{~m}$ at full extension). Flux observations are expected to be representative of the integrated surface rather than its individual elements (buildings, trees, roads, etc.) over horizontal length scales of about $10^{2}-10^{4} \mathrm{~m}$, referred to as the local scale. For this to be ensured, measurements need to be made above the blending height $\left(z_{r}\right)$ in the surface layer, which is the limit of the influence of the roughness sub-layer. However, the depth of the roughness sub-layer is a subject of much debate. Roth (2000) stated that, though simplistic, it is instructive to calculate $z_{r}$ as a function of the most available parameter $z_{\mathrm{Hb}}$. With a few exceptions the values of $z_{r} / z_{H b}$ reported in his review of turbulence over cities correspond well with those from Raupach et al. (1991), also from a review of atmospheric and laboratory boundary layers over rough surfaces, and found values in the range of 2-5 for momentum. It is possible that these limiting values are larger for heat (Roth 2000). Grimmond and Oke (1999a) also suggested that $z_{r}$ values between 15 and $40 \mathrm{~m}$ are typical of residential areas. Thus, our $z_{m}$ value at the Greenwood site, which gives an estimated $z_{r} / z_{H}$ ratio of $\approx 5.0$, is expected to be in the inertial sublayer and well above the blending height. The validity of this assumption was also investigated from the velocity, temperature and humidity spectra 
Table 2 Input parameters and dimensions of the 50\% turbulent flux source area computed using FSAM (Schmid 1994) and evaluated at $z^{\prime}=30 \mathrm{~m}$

\begin{tabular}{lccccccc}
\hline$z^{\prime} / z_{o}$ & $z^{\prime} / L$ & $\sigma_{v} / u_{*}$ & $a(\mathrm{~m})$ & $e(\mathrm{~m})$ & $d(\mathrm{~m})$ & $x_{d}(\mathrm{~m})$ & $A_{r}\left(\mathrm{~km}^{2}\right)$ \\
\hline 43.5 & 0.05 & 2.26 & 52.9 & 3,550 & 588 & 1,900 & 3.160 \\
43.5 & -0.15 & 1.80 & 45.8 & 1,200 & 208 & 647 & 0.375 \\
43.5 & -0.20 & 2.09 & 43.9 & 1,060 & 220 & 571 & 0.350 \\
43.5 & -0.49 & 2.57 & 35.4 & 687 & 193 & 371 & 0.198 \\
43.5 & -0.82 & 3.34 & 29.1 & 515 & 203 & 278 & 0.156 \\
43.5 & -1.23 & 5.00 & 23.3 & 388 & 251 & 210 & 0.145 \\
\hline
\end{tabular}

$z_{o}$ is the roughness length $(0.69 \mathrm{~m}), a$ is the near end, $e$ is the far end, $d$ is the maximum lateral half-width, $x_{d}$ is the upwind distance of $d$, and $A_{r}$ is the surface area of the ellipse

(not presented here); the power spectra show an approximate $f^{-5 / 3}$ slope from frequencies of $0.1 \mathrm{~s}^{-1}$ upwards, suggesting that this encompasses the inertial sub-range.

However, the depth of the physical blending height also varies with mixing activity and stability (Schmid 1997), and thus it is important to calculate source areas for the turbulent fluxes. The source areas for the Greenwood fluxes were estimated using a version of the flux source area model FSAM (Schmid 1994; 1997). The 50\% source areas (i.e., the area enclosing $50 \%$ of the surface influence) for an instrument at $z^{\prime}=30 \mathrm{~m}$ were calculated, where $z^{\prime}=z_{m}-z_{d}$. The dimensions describing the shape of the ellipsoid are given in Table 2 together with the input variables for representative night and daytime conditions. The results show that the size of the $50 \%$ source weight area increases with increasing stability, whereas its length and width decreases as atmospheric stability changes from stable to neutral to unstable conditions (Table 2). The source-area estimates were also used to screen out flux observations made under stable conditions when the flux footprint was outside our area of interest. There was uniform fetch for a distance of $>600 \mathrm{~m}$ in all directions from the tower except the north-east and east sectors, and so we used only data from $135^{\circ}$ to $360^{\circ}$ in our analyses. The predominant wind direction during the study period corresponded with this sector (see Sect. 2.3).

A sonic anemometer design with improved performance capabilities in rainy conditions (Campbell Scientific model CSAT3) and krypton hygrometer (Campbell Scientific model $\mathrm{KH} 20$ ) were mounted on booms extending approximately $1.2 \mathrm{~m}$ from the top of the tower, oriented south-westward $\left(225^{\circ}\right.$ in the direction of the most densely built area and longest fetch). The krypton hygrometer was mounted at the same height as, and separated laterally from, the centre of the sonic anemometer's measuring volume by $0.20 \mathrm{~m}$. Meteorological conditions were measured using a net radiometer (REBS model Q7-1); a temperature and relative humidity sensor (Vaisala model HMP45C); a wind speed and direction sensor (RM Young, 03101-L); an albedometer (consisting of and upward and a downward facing pyranometer, Kipp and Zonen model SP-Lite-L); and an infrared thermometer to measure surface temperature. Dry-bulb and wet-bulb temperatures, atmospheric pressure, and precipitation were measured at the base of the tower. All instruments were new and were calibrated and delivered by the manufacturers within a month of the start of the field measurements. Instruments were mounted to ensure that they had minimal interference from the tower and that they were properly leveled. All data were logged on a Campbell Scientific CR5000 data logger in an enclosure attached to the tower and downloaded with a laptop computer. The system was powered by two solar panels and a deep-cycle marine battery. See Table 3 for a listing of the instruments and the heights at which they were deployed. The investigators 
Table 3 Instrumentation used at the study site

\begin{tabular}{|c|c|c|c|}
\hline Variables & Instrument & Model & Height (m) \\
\hline $\begin{array}{l}\text { Wind speed }(u) \\
\text { and direction }(\theta)\end{array}$ & $\begin{array}{l}\text { Anemometer and } \\
\text { wind vane }\end{array}$ & $\begin{array}{l}\text { RM Young Wind } \\
\text { Sentry 03101-L }\end{array}$ & 35 \\
\hline $\begin{array}{l}\text { Wind speed and } \\
\text { temperature } \\
\text { fluctuations } \\
\left(u^{\prime}, v^{\prime}, w^{\prime}, T_{v}^{\prime}\right)\end{array}$ & Sonic anemometer & CSI CSAT3 & 35 \\
\hline Humidity fluctuations $\left(q^{\prime}\right)$ & Krypton hygrometer & CSI KH20 & 35 \\
\hline $\begin{array}{l}\text { Air temperature \& relative } \\
\text { humidity }(T, R H)\end{array}$ & $\begin{array}{l}\text { Thermometer and } \\
\text { humidity probe }\end{array}$ & Vaisala HMP45C-L & 35 \\
\hline $\begin{array}{l}\text { Wet- and dry-bulb } \\
\text { temperatures } \\
\left(T, T_{w}\right)\end{array}$ & $\begin{array}{l}\text { Dry- and wet-bulb } \\
\text { psychrometers }\end{array}$ & $\begin{array}{l}\text { Enercorp Inst. } \\
\text { HT-WD-A } \\
\text { ventilated } \\
\text { psychrometers }\end{array}$ & 32,26 \\
\hline $\begin{array}{l}\text { Shortwave radiation } \\
\qquad(S \downarrow, S \uparrow) \text { and } \\
\text { albedo }(\alpha)\end{array}$ & Pyranometers & Kipp \& Zonen SP-Lite-L & 32 \\
\hline Net radiation $\left(R_{n}\right)$ & Net radiometer & REBS Q7-1 & 32 \\
\hline Surface temperature $\left(T_{\text {surf }}\right)$ & Infrared thermometer & Apogee IRTS-P & 32 \\
\hline Air pressure $(P)$ & Barometer & Vaisala CS105 & 25 \\
\hline Precipitation & Tipping bucket rain gauge & CSI TE525MM-L & \\
\hline Data logging & Data logger & CSI CR5000 & \\
\hline Tower & Mobile telescoping mast & US Tower MTU3107MDPLHD & \\
\hline
\end{tabular}

were on-site throughout the intensive observation period, and the system was checked daily, including verifying the level of the sonic anemometer and the radiometers, and cleaning moisture and dust from the krypton hygrometer and the radiometers. A mobile industrial crane was available at the site throughout the measurement period that facilitated access to the system on the mast for maintenance.

The turbulent fluxes $\left(Q_{H}\right.$ and $\left.Q_{E}\right)$ were determined using the eddy-covariance technique. The high-frequency $10 \mathrm{~Hz}$ turbulence measurements of vertical wind speed, temperature, and humidity were used to compute the correlation between vertical velocity and the atmospheric scalar variables of interest. The flux data presented here have been computed directly from this correlation using 30-min averaging periods. All times referred to are local time, with the time indicating the hour ending. Preliminary online flux calculations were computed on the data logger and stored on a compact flash disk, to permit assessment of the data quality during the intensive observation period. Then, the raw turbulence data were re-processed using the University of Bayreuth turbulence flux data processing software, Turbulenzknecht 2 (TK2; Foken et al. 2004; Mauder and Foken 2004). The flux calculation correction procedures implemented in TK2 included (i) spike detection and rejection algorithms (Vickers and Mahrt 1997), (ii) coordinate rotation using the planar fit method (Wilczak et al. 2001), (iii) double rotation for aligning the wind component $u$ with the mean wind direction and setting the mean values of $v$ and $w$ to zero, (iv) Conversion of sonic virtual temperature to air temperature after Schotanus et al. (1983), (v) correction of oxygen cross sensitivity for the Krypton hygrometer (Tanner et al. 1993; Van Dijk et al. 2003 ), (vi) correction for spectral loss after Moore (1986), (vii) density fluctuation corrections for water vapour (Webb et al. 1980; Liebethal and Foken 2003), and (viii) tests of stationarity and integral turbulence characteristics (Foken et al. 2004). Following Foken and Wichura (1996), we subjected all flux data and calculated statistics to strict data limits to reject spurious values, and to 
quality-control flags based on integral turbulence characteristics; only data with quality flags 1-5 for fluxes and 1-3 for integral turbulence characteristics were used in the following analyses. After performing the flux corrections of the eddy-covariance measurements mentioned above, the uncertainty in turbulent transport has also been discussed as the primary source of flux uncertainty by several authors (e.g., Lenschow et al. 1994; Mann and Lenschow 1994; Finkelstein and Sims 2001) and needs to be quantified. The fluxes above the Greenwood site are determined with relative random uncertainties of 10-15\% for sensible heat and 20-30\% for latent heat by day and higher at night. The estimated relative random error of the net radiation measurement is $3-5 \%$.

Data capture and quality were good as the CSAT3 sonic anemometer design used had modifications that improved its performance under rainy conditions. These modifications consisted of a new internal processing module in the CSAT3 that is more immune to raindegraded signals, and water wicks on the transducers that prevent large drops of water that completely obscure the sonic signals from collecting on the transducer face. There were a few missing half-hourly data in the diurnal series as a result of data quality control and rejection algorithms executed in TK2. The percentage of the missing data was approximately $15 \%$, for which gaps of one to a few half-hourly values were linearly interpolated and gaps exceeding this length were filled using the mean diurnal variation method (Moffat et al. 2007).

It is not practical to measure the heat storage flux $\left(\Delta Q_{S}\right)$ directly at suburban sites due to the complexity of the urban surface and the diversity of material types of which the urban fabric is composed (Grimmond and Oke 1999b). A recent evaluation of available models to estimate $\Delta Q_{s}$ (Robert et al. 2006) reveal that most methods tend to slightly overestimate storage uptake by day while others slightly underestimate it, and all methods underestimate heat storage release at night when compared with $\Delta Q_{s}$ values determined as a residual of the other measured fluxes. Also the extensive input requirements for some of the models render them almost impractical. While the convergence of results is reassuring, Robert et al. (2006) concluded that the lack of a standard for quantifying heat storage still remains a source of imprecision in urban energy balance measurement and modelling. In this study $\Delta Q_{s}$ was determined as a residual in the energy balance $\left[\Delta Q_{s}=R_{n}-\left(Q_{H}+Q_{E}\right)\right]$; the limitation with this is that measurement errors of the other energy balance fluxes accumulate in this term. These errors include those that may be due to spatial inconsistency of the energy balance terms, because the source area of the turbulent fluxes varies as a function of wind speed and direction, atmospheric stability and surface roughness, whereas for the radiant fluxes it is fixed in time. Additional error is introduced in the residual $\Delta Q_{s}$ because neither anthropogenic heat $Q_{F}$ from combustion and sources or sinks due to advection $\Delta Q_{A}$ from cooler or warmer surfaces upwind is included. It is not known whether there are significant regional scale circulations that are generated due to differential heating patterns between land and Lake Winnebago at our Greenwood flux-tower site that is less than $5 \mathrm{~km}$ from the lake (Fig. 1). However for the Sunset neighborhood in Vancouver, where the surrounding coastal ocean generates a sea-breeze circulation, Steyn (1985) concluded that advection could be neglected at the local scale when working under similar land-use conditions. In a continental area of the U.S.A. similar to our study site, Rabin et al. (1990) found that inland lakes affected boundary-layer development and suppressed cloud formation. Lake Winnebago is a narrow body of water that is approximately $400 \mathrm{~m}$ wide at its widest point and just less than $1,500 \mathrm{~m}$ long at maximum. These dimensions are on the low end of the lake sizes that Rabin et al. (1990) showed could produce boundary-layer effects, and that these effects are more evident under calm conditions and would tend to disappear during windier mid-day conditions. Given the study area characteristics, the location of the main potential sources relative to the measurement site, and the size of $Q_{F}$ found at suburban and urban locations 
in North America (Grimmond 1992; Sailor and Lu 2004), we estimate that advective effects are small. However, all such errors accumulate in $\Delta Q_{s}$, and this must be taken into account in interpreting our estimate of heat storage by the exurban surface.

\subsection{Meteorological Conditions}

Weather conditions during the measurement period were relatively mild with generally sunny days characterized by a pronounced diurnal cycle (Fig. 3). Winds were from all directions during the measurement period, with a mean speed of $3.5 \mathrm{~m} \mathrm{~s}^{-1}$ and a maximum sometimes exceeding $7 \mathrm{~m} \mathrm{~s}^{-1}$, but the prevailing winds were mainly from the south (Fig. 3). Two distinct sky conditions were also observed during the measurement period; cloudy throughout the day (6 days) and near clear-sky conditions (11 days). The cloudy days had $>75 \%$ cloud cover consisting of mainly cumulus and cumulonimbus clouds. The near clear-sky days had $<10 \%$ cloud cover consisting of fair weather cumulus clouds that formed just after noon and cleared two to three hours later. Air temperature and vapour pressure deficit followed the diurnal circle and were lower and higher for cloudy and near clear-sky conditions, respectively (Fig. 3). The maximum air temperature recorded during our intensive observation period was $30.8^{\circ} \mathrm{C}$, while the average air temperature was 22.4 and $18.5^{\circ} \mathrm{C}$ for cloudy and near clear-sky days, respectively. This maximum is $0.9^{\circ} \mathrm{C}$ lower than the $1971-2000$ normal (NCDC-NOAA summary 2004). The vapour pressure deficits were low, ranging from 0.66 to $1.2 \mathrm{kPa}$ and from 0.32 to $1.9 \mathrm{kPa}$ for cloudy and near clear-sky conditions, respectively (Fig. 3). There was $18 \mathrm{~mm}$ of rainfall on August 4 and there were small $(<0.35 \mathrm{~mm})$ precipitation events on three other days during the measurement period. A total of $155 \mathrm{~mm}$ of rain fell during August 2004 compared to the climatic norm of $122 \mathrm{~mm}$, which followed a similar pattern to July and produced a wet summer relative to average (NOAA-NCDC 2004). However, the daily precipitation record showed that most of the August precipitation occurred after our intensive observation period had ended (129 mm out of $155 \mathrm{~mm}$ for the month). There was no rain during the 7 days preceding the intensive observational period and a total of $26 \mathrm{~mm}$ of rainfall occurred during our measurements. Overall, meteorological conditions during our measurement period did not differ significantly from typical summer conditions in the region, but soil moisture conditions were clearly elevated throughout the mid to late summer period. Typical of new developments, the neighbourhood we studied was built with automated irrigation systems, which similarly would tend to maintain high soil moisture levels, regardless of precipitation.

\section{Results and Discussion}

\subsection{Surface Energy Partitioning}

A summary of the mean summertime measurements of exurban surface energy balance fluxes at Greenwood is given in Table 4 for the measurement period. The data presented are the mean for daytime (hours when $R_{n}>0$ ), and daily (24-h) periods for the cloudy and near clear-sky conditions observed. In addition, five ratios are also given in the Table: the three fluxes normalized by the net radiation $\left(\gamma=Q_{H} / R_{n}, \chi=Q_{E} / R_{n}\right.$ and $\left.\Lambda=\Delta Q_{s} / R_{n}\right)$, Bowen ratio ( $\beta=Q_{H} / Q_{E}$ ), and the ratio of the sensible heat flux to the atmosphere and the residual heat storage ( $\left.\kappa=Q_{H} / \Delta Q_{S}\right)$. These ratios give information on the energy partitioning and relative trends of the fluxes through the day. Weather conditions were similar for the days under cloudy skies, while days under near clear-sky conditions also had similar characteristics. 

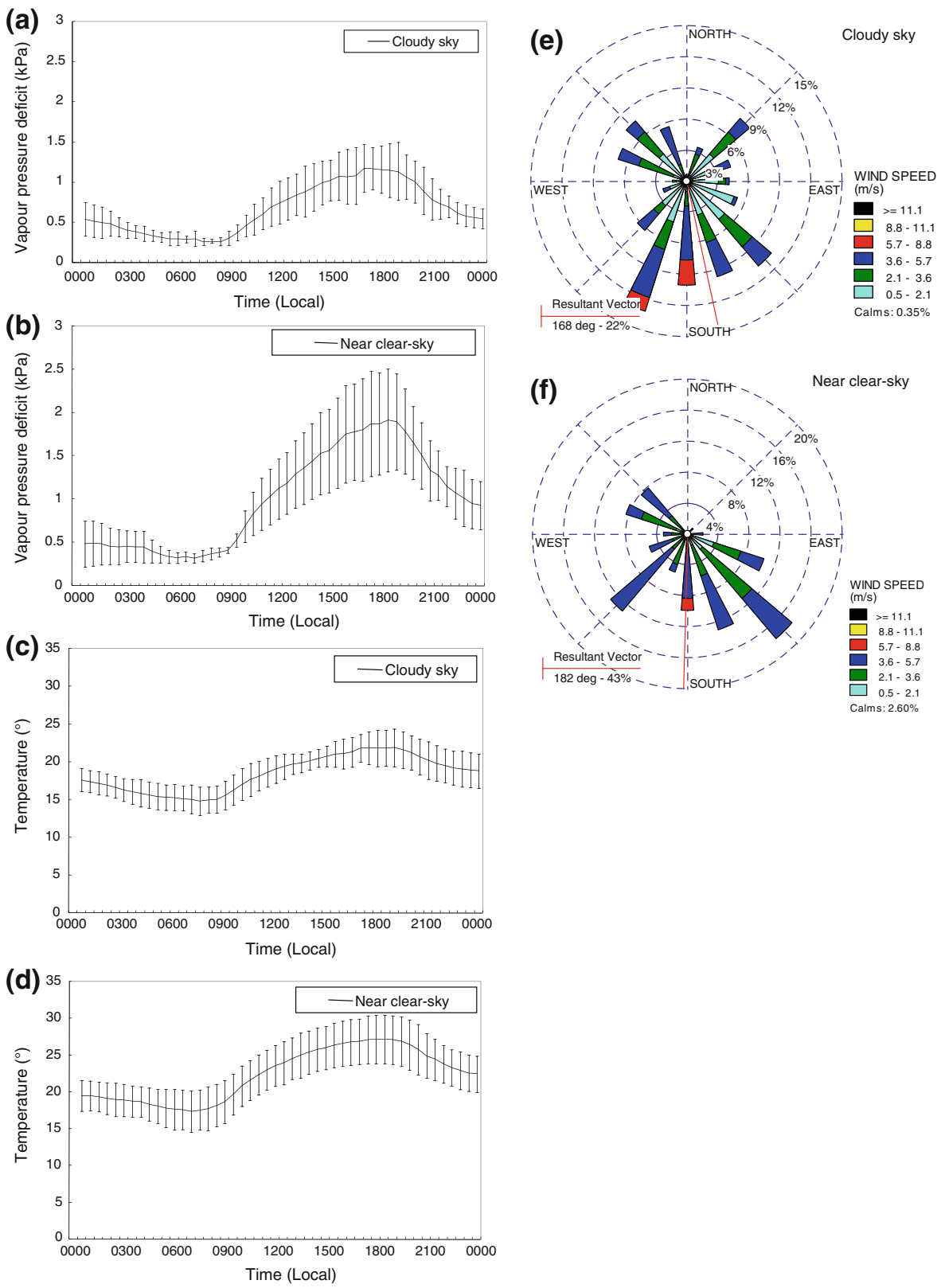

Fig. 3 Meteorological conditions observed on the tower during the measurement period for ensemble hourly averages of vapour pressure deficit, air temperature, wind speed and wind direction under cloudy sky (a, c, e) and near clear-sky $(\mathbf{b}, \mathbf{d}, \mathbf{f})$ conditions respectively. Error bars are $\pm 1 \sigma$

Thus, an ensemble mean day (consisting of a mean of all data for each half-hour under each cloud condition) gives a representative partitioning between terms in the energy balance. 
Table 4 Daytime $\left(R_{n}>0\right)$ and daily (24-h) mean energy fluxes and ratios for cloudy and near clear sky conditions

\begin{tabular}{|c|c|c|c|c|c|c|c|c|c|}
\hline \multicolumn{5}{|c|}{ Energy fluxes $\left(\mathrm{W} \mathrm{m}^{-2}\right)$} & \multicolumn{5}{|c|}{ Ratios } \\
\hline$n$ & $R_{n}$ & $Q_{H}$ & $Q_{E}$ & $\Delta Q_{s}$ & $\beta$ & $\gamma$ & $\chi$ & $\Lambda$ & $\kappa$ \\
\hline \multicolumn{10}{|c|}{ Daytime cloudy sky conditions $\left(R_{n}>0\right)$} \\
\hline 13 & 254 & 56 & 120 & 79 & 0.46 & 0.22 & 0.47 & 0.31 & 0.70 \\
\hline \multicolumn{10}{|c|}{ Daily cloudy sky conditions $(24 h)$} \\
\hline 144 & 114 & 23 & 66 & 23 & 0.39 & 0.23 & 0.58 & 0.20 & 1.14 \\
\hline \multicolumn{10}{|c|}{ Daytime near clear-sky conditions $\left(R_{n}>0\right)$} \\
\hline 13 & 370 & 81 & 169 & 100 & 0.48 & 0.21 & 0.46 & 0.27 & 0.81 \\
\hline \multicolumn{10}{|c|}{ Daily near clear-sky conditions $(24 h)$} \\
\hline 216 & 171 & 40 & 91 & 31 & 0.44 & 0.23 & 0.53 & 0.18 & 1.26 \\
\hline \multicolumn{10}{|c|}{ Daytime all-sky conditions $\left(R_{n}>0\right)$} \\
\hline 184 & 312 & 68 & 145 & 89 & 0.47 & 0.22 & 0.46 & 0.29 & 0.76 \\
\hline \multicolumn{10}{|c|}{ Daily all-sky conditions $(24 h)$} \\
\hline 360 & 143 & 33 & 78 & 27 & 0.41 & 0.23 & 0.55 & 0.18 & 1.21 \\
\hline
\end{tabular}

The ratios are defined as $\gamma=Q_{H} / R_{n}, \chi=Q_{E} / R_{n}, \Lambda=\Delta Q_{s} / R_{n}$, Bowen ratio $\left(\beta=Q_{H} / Q_{E}\right)$ and $\kappa=Q_{H} / \Delta Q_{s}$. Daytime $n$ is the average number of hours used within each day where $R_{n}>0$; daily $n$ is the total number of hours analyzed

\subsection{Net Radiation and Surface Albedo}

The diurnal course of the net all-wave radiation under both cloudy and near clear-sky conditions exhibited similar patterns for the days falling under the two conditions, with lower values and higher variability under the cloudy condition as would be expected (Fig. 4a, b). Net radiation increased rapidly from dawn $\left(-34\right.$ and $\left.-58 \mathrm{~W} \mathrm{~m}^{-2}\right)$ during the night to reach a maximum (423 and $630 \mathrm{~W} \mathrm{~m}^{-2}$ ) after midday for cloudy and near clear-sky conditions respectively. Mean daytime values are 253 and $368 \mathrm{~W} \mathrm{~m}^{-2}$, respectively for the cloudy and near clear-sky conditions, while mean daily values are 114 for cloudy and $144 \mathrm{~W} \mathrm{~m}^{-2}$ for near clear-sky conditions, respectively (Table4). These values are similar in magnitude but slightly higher than those reported in the literature for suburban locations in some North American cities (Grimmond and Oke 1995, 1999b; Offerle et al. 2003). This is consistent with the higher albedo and lower surface temperature observed at our Greenwood site.

The surface albedo was determined from the measurements of the albedometer when both the incoming $(S \downarrow)$ and reflected solar radiation $(S \uparrow)$ were greater than $10 \mathrm{~W} \mathrm{~m}^{-2}$, as $\alpha=S \uparrow / S \downarrow$. Its diurnal variation under both cloudy and near clear-sky conditions is shown in Fig. 4c. The surface albedo also exhibited a dependence on solar elevation, with a tendency to be greater at dawn and dusk (when solar elevation angle is low) and to have its minimum at solar noon (maximum solar elevation angle). This pattern of variation has been widely observed over a wide range of land-use types (Oke 1987; Allen et al. 1994; Christen and Vogt 2004; Grimmond et al. 2004a,b), and results from deeper penetration of the canopy by the solar beam at high solar elevation, causing more radiation to be absorbed. Figure 4d illustrates this angular dependence for the Greenwood site. However the pattern of the angular dependence differed from recent observations over urban and suburban surfaces, where it was observed that the angular dependence becomes important when solar elevation is $<20^{\circ}$, due to the highly directional reflectance of horizontal surfaces and is fairly 
Fig. 4 Ensemble

hourly-averaged net radiation for a cloudy sky, b near clear sky conditions, c ensemble hourly averaged albedo, and $\mathbf{d}$ angular dependence of albedo on solar elevation
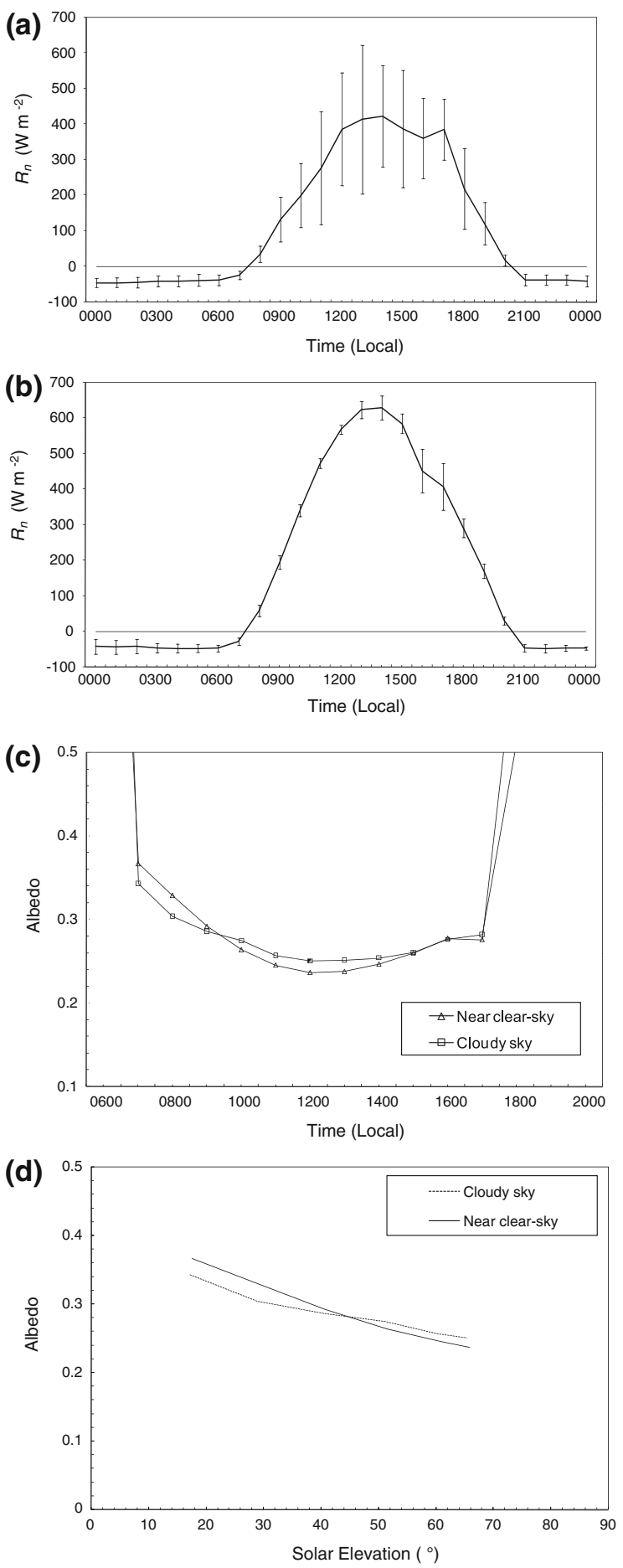
constant between $20^{\circ}$ and $65^{\circ}$ solar elevation under both clear-sky and overcast conditions (Christen and Vogt 2004). The pattern at the Greenwood site is similar to observations over vegetated surfaces (Allen et al. 1994; Christen and Vogt 2004), where albedo is increased in general under clear-sky conditions at low solar elevation and decreased under cloudy conditions at high solar elevation (Fig. 4d). The measured mean minimum surface albedo was 0.25 and 0.24 at solar noon for the cloudy and near clear-sky conditions respectively. The increase in the variation of diffuse radiation during cloudy conditions is responsible for the slight increase of albedo around solar noon compared to near clear-sky conditions; this is in agreement with Allen et al. (1994). These values are higher than albedo values observed for suburban areas, which averaged 0.15 in a survey of suburban field studies (Oke 1987). The closest to the values reported here are Chicago, Illinois with values that ranges from 0.23 to 0.16 for non-snow conditions (Offerle et al. 2003) and Miami, Florida with values that ranges from 0.20 to 0.14 for all sky conditions (Newton et al. 2007). These high observed surface albedo values are not unexpected given the extensive luxuriant grass lawns and highly reflective light coloured coatings of the more widely spaced single storey buildings, see Fig. 2. This is also consistent with the results of Offerle et al. (2003) and Christen and Vogt (2004), who conclude that albedo decreases with increasing height and density of buildings.

The higher vegetation cover at this site (58\%) mentioned earlier, compared to earlier studies with more developed urban surfaces, appears to be an important factor in the surface radiation budget, given its low surface temperature (mean maximum surface temperature was 24.5 and $28.9^{\circ} \mathrm{C}$ for the cloudy and near clear-sky conditions, respectively), leading to a relatively low upward longwave radiation flux and high $Q_{E}$ flux (see Sect.3.3 where persistent wet surface conditions may have contributed to the observed higher net radiation values). It is also possible that the air pollution level at this site is lower compared to the larger and older suburban locations with more anthropogenic activities.

\subsection{Latent Heat Flux, Sensible Heat Flux and Bowen Ratio}

\subsubsection{Latent Heat Flux}

The prevailing weather for the two distinct sky conditions observed during the measurement period were similar and a simple ensemble mean day (consisting of a mean of all data for each hour) gives a representative illustration of energy partitioning between the energy balance terms (Fig. 5), for the cloudy and near clear-sky conditions. During the day energy partitioning is dominated by the convective transport of latent heat $\left(Q_{E}\right)$, followed by the conductive sensible heat storage $\left(\Delta Q_{S}\right)$ and the smallest fraction is used up in convective sensible heating of the air $\left(Q_{H}\right)$. The phase of the fluxes is different, with $\Delta Q_{S}$ peaking 1-2 $\mathrm{h}$ after noon, and $Q_{E}$ and $Q_{H}$ in the late afternoon. The net radiation loss at night is almost totally matched by the release of heat from storage in the suburban fabric, while $Q_{E}$ is small but positive all through the night. This diurnal balance pattern is similar to those observed in several suburban sites in North America (Grimmond et al. 1994; Grimmond and Oke 1995, 1999b; Newton et al. 2007).

The diurnal variation and absolute magnitudes of the ensemble-mean $Q_{E}$ flux in Greenwood, Kansas City (Fig. 5) are similar to those observed in North American suburbs. However, the Greenwood values are higher compared to the suburban sites (Grimmond et al. 1994; Grimmond and Oke 1995, 1999b; Newton et al. 2007). This is not unexpected since the increased availability of heat and moisture at the surface over a largely vegetated humid 

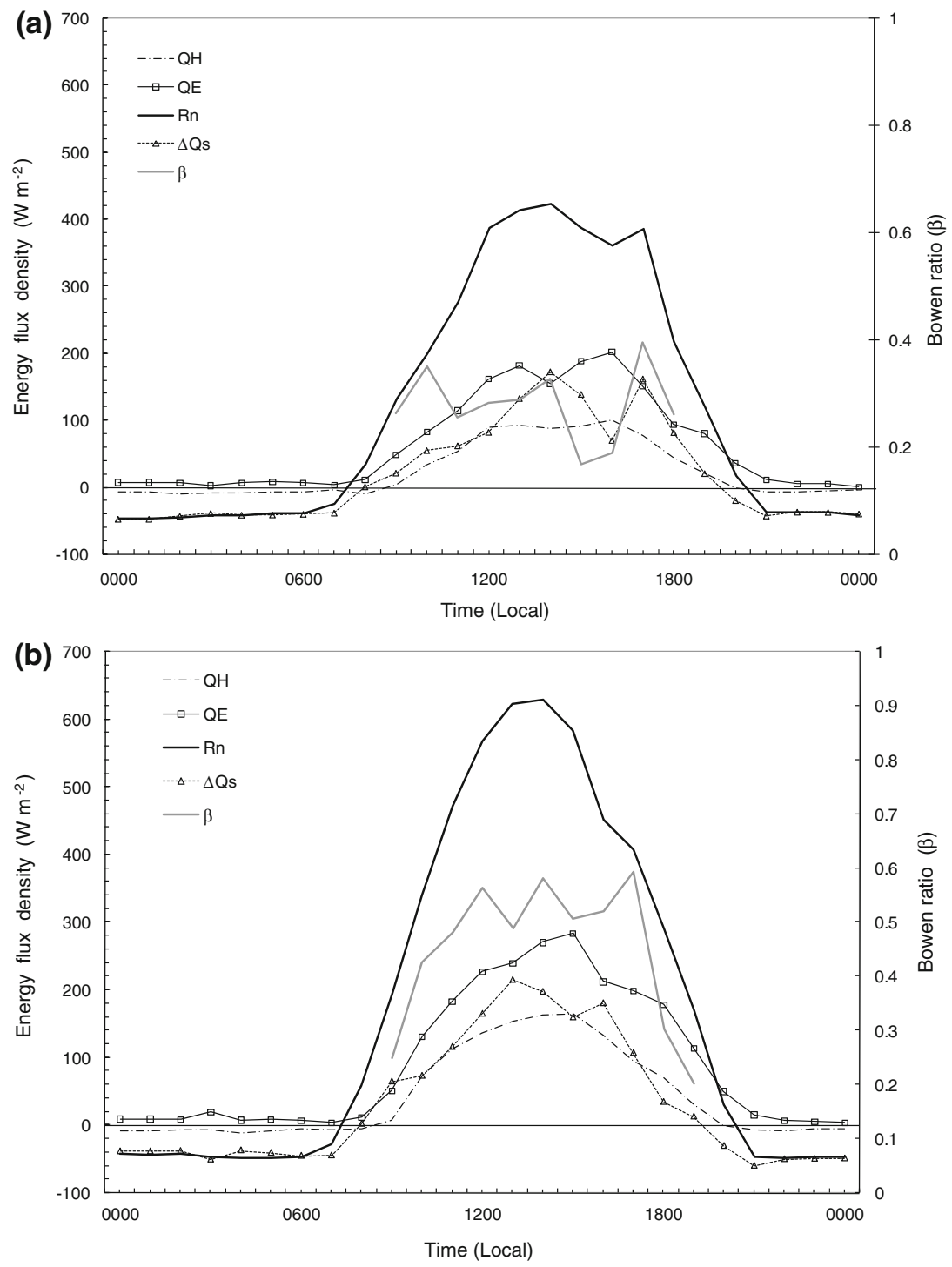

Fig. 5 Ensemble hourly-averaged energy flux densities and Bowen ratio for a cloudy sky and $\mathbf{b}$ near clear sky conditions

continental city with frequent precipitation probably increases evapotranspiration. The observed pattern is a bimodal curve with its maximum peak at 1600 local time for cloudy conditions and a unimodal curve with its peak at 1500 local time for near clear-sky conditions respectively (Fig. 5a, b). However, it is presently not known whether the bimodal distribution observed in Fig. 5a is an artifact of limited data, so that when averaged over a longer period of record, the secondary peak may disappear. As observed at most suburban sites, evapotranspiration remains positive, although small, throughout the night. Mean daytime values are 120 and $167 \mathrm{~W} \mathrm{~m}^{-2}$, respectively for the cloudy and near clear-sky conditions, while 
also the mean daily values are 66 and $91 \mathrm{~W} \mathrm{~m}^{-2}$, respectively. The mean daytime and daily values for all-sky conditions are 145 and $78 \mathrm{~W} \mathrm{~m}^{-2}$ (Table 4). $Q_{E}$ dominated the energy partitioning throughout the measurement period, and the fractions of net radiation devoted to $Q_{E} \quad\left(\chi=\frac{Q_{E}}{R_{n}}\right)$ under cloudy conditions were 47 and $58 \%$ for the daytime and daily ensemble averages respectively. The corresponding percentages for near clear-sky conditions were 46 and 53\% and for all-sky conditions were 46 and 55\% respectively (Table 4). The daytime $\chi$ values were similar for all sky conditions $46-47 \%$, but the 24 -h mean was higher 53-58\%. Figure 6 also shows the diurnal variation of the normalized fluxes with higher $\chi$ ratios under cloudy conditions compared to near clear-sky conditions. The decrease under near clear-sky conditions is not due to a reduction in evapotranspiration rate as can be noted in Fig. 5b, since water is not limiting, but the enhancement of $Q_{H}$ as the surface gradually dried on subsequent near cloud-free days without rain (Figs. 5b, 6). It was also observed that weak (small positive values of the order of $10-20 \mathrm{~W} \mathrm{~m}^{-2}$ ) evapotranspiration occurs throughout the night on a daily basis, but sometimes this exceeds $30 \mathrm{~W} \mathrm{~m}^{-2}$ (Fig. 5). The diurnal pattern of $\chi$ is similar to those of other cities in North America; Chicago, Los Angeles, Sacramento, Tucson and Miami (Grimmond and Oke 1995; Grimmond et al. 1994). In all these cities $Q_{E}$ is almost always positive at night. Apart from the sunrise/sunset periods and under cloudy conditions, the $\chi$ values also exhibit very little variation throughout the daytime and follow an opposite/mirror image pattern to that of the ratio of the storage heat flux to the net radiation flux $\left(\Lambda=\frac{\Delta Q_{s}}{R_{n}}\right)$ (Fig. 6). The daytime evapotranspiration rates and $\chi$ value of 0.46 for all sky conditions observed in this study are higher than suburban areas with high summer evapotranspiration rates in North America, e.g. Chicago, Los Angeles and Miami (Grimmond et al. 1994; Grimmond and Oke 1995, 1999b; Oke et al. 1999; Newton et al. 2007). Table 5 show comparable values for residential suburbs in North American cities to range from 0.22 to 0.38 and the closest to the results of this study is Chicago.

\subsubsection{Sensible Heat Flux}

The maximum daily sensible heat flux $\left(Q_{H}\right)$ occurs at the same time as $Q_{E}$ and exhibits the same pattern of variation as the latent heat flux for both cloudy and near clear-sky conditions (Fig. 5). The ensemble mean daytime $\left(R_{n}>0\right)$ values reached a maximum of 101 and $164 \mathrm{~W} \mathrm{~m}^{-2}$ at 1600 and $1500 \mathrm{~h}$ for the cloudy and near clear-sky conditions respectively (Fig. 5). The sensible heat flux values at the Greenwood, Kansas City site become negative at $2100 \mathrm{~h}$, the same time as $R_{n}$, and then remain negative throughout the night until after sunrise (Fig. 5), a notable difference from observations from fully urbanized sites e.g. Mexico City, Mexico and Marseilles, France (Oke et al. 1999; Grimmond et al. 2004b). This site is dominated by well-watered luxuriant grass lawns, so this result is not surprising and is consistent with observations at suburban areas with large amounts of vegetation e.g. Chicago, Tucson and Oklahoma City (Grimmond et al. 1994, 2004a; Grimmond and Oke 1995).

Mean daytime values are 56 and $81 \mathrm{~W} \mathrm{~m}^{-2}$ respectively for the cloudy and near clear-sky conditions, while the mean daily values are 26 and $40 \mathrm{~W} \mathrm{~m}^{-2}$, respectively. The mean daytime and daily values are 68 and $33 \mathrm{~W} \mathrm{~m}^{-2}$ respectively for all-sky conditions (Table 4$)$. The fraction of $R_{n}$ partitioned into $Q_{H}\left(\gamma=\frac{Q_{H}}{R_{n}}\right)$ shows remarkably little day-to-day variability especially in the daytime (Fig. 6), irrespective of weather conditions, with a mean value of 0.22 for all-sky conditions (Table 4). This is consistent with the dominant $Q_{E}$ being offset by $\Delta Q_{S}$ leaving a relatively constant fraction of the net radiation for $Q_{H}$. This value is also the lowest in the range of values observed in urban areas (Table 4). 
Table 5 Summary of mean daytime $\left(R_{n}>0\right)$ flux ratios for all-sky conditions at our exurban Kansas City site and at suburban sites in North America

\begin{tabular}{|c|c|c|c|c|c|c|c|c|c|}
\hline \multirow[b]{2}{*}{ City } & \multirow[b]{2}{*}{$\begin{array}{l}\text { Site } \\
\text { code }\end{array}$} & \multirow[b]{2}{*}{ Land use } & \multirow[b]{2}{*}{$\begin{array}{l}\text { Obs } \\
\text { period }\end{array}$} & \multirow[b]{2}{*}{$\begin{array}{l}\text { Original } \\
\text { reference }\end{array}$} & \multicolumn{5}{|c|}{ Ratios } \\
\hline & & & & & $\beta$ & $\gamma$ & $\chi$ & $\Lambda$ & $\kappa$ \\
\hline $\begin{array}{l}\text { Kansas } \\
\text { City, MO }\end{array}$ & (Kc04) & $\begin{array}{l}\text { Exurban } \\
\text { residential }\end{array}$ & Aug 2004 & This study & 0.47 & 0.22 & 0.46 & 0.29 & 0.76 \\
\hline $\begin{array}{l}\text { Vancouver, } \\
\text { BC }\end{array}$ & (Vs92) & $\begin{array}{l}\text { Suburban } \\
\text { residential }\end{array}$ & $\begin{array}{l}\text { Jul/Sep } \\
1992\end{array}$ & $\begin{array}{l}\text { Grimmond } \\
\text { and Oke } \\
\text { (1999b) }\end{array}$ & 2.87 & 0.62 & 0.22 & 0.17 & 3.70 \\
\hline $\begin{array}{l}\text { Vancouver, } \\
\text { BC }\end{array}$ & (Vs89) & $\begin{array}{l}\text { Suburban } \\
\text { residential }\end{array}$ & Jul 1989 & $\begin{array}{l}\text { Roth and Oke } \\
\text { (1994) }\end{array}$ & 1.97 & 0.54 & 0.27 & 0.19 & 1.70 \\
\hline $\begin{array}{l}\text { Los Angeles, } \\
\text { CA }\end{array}$ & $(\mathrm{Sg} 94)$ & $\begin{array}{l}\text { Suburban } \\
\text { residential }\end{array}$ & Jul 1994 & $\begin{array}{l}\text { Grimmond } \\
\text { et al. } \\
\text { (1996) }\end{array}$ & 2.17 & 0.49 & 0.22 & 0.29 & 1.68 \\
\hline $\begin{array}{l}\text { Los Angeles, } \\
\text { CA }\end{array}$ & (A94) & $\begin{array}{l}\text { Suburban } \\
\text { residential }\end{array}$ & Jul 1994 & $\begin{array}{l}\text { Grimmond } \\
\text { et al. } \\
\text { (1996) }\end{array}$ & 1.61 & 0.43 & 0.26 & 0.31 & 1.37 \\
\hline $\begin{array}{l}\text { Los Angeles, } \\
\text { CA }\end{array}$ & (A93) & $\begin{array}{l}\text { Suburban } \\
\text { residential }\end{array}$ & $\begin{array}{l}\text { Jul/Aug } \\
1993\end{array}$ & $\begin{array}{l}\text { Grimmond } \\
\text { and Oke } \\
\text { (1995) }\end{array}$ & 1.24 & 0.39 & 0.31 & 0.30 & 1.27 \\
\hline Tucson, AZ & (T90) & $\begin{array}{l}\text { Suburban } \\
\text { residential }\end{array}$ & Jun 1990 & $\begin{array}{l}\text { Grimmond } \\
\text { and Oke } \\
\text { (1995) }\end{array}$ & 2.08 & 0.52 & 0.25 & 0.23 & 2.24 \\
\hline Miami, FL & (Mi95) & $\begin{array}{l}\text { Suburban } \\
\text { residential }\end{array}$ & $\begin{array}{l}\text { May/Jun } \\
1995\end{array}$ & $\begin{array}{l}\text { Newton } \\
\text { (1999); } \\
\text { Newton } \\
\text { et al. } \\
(2007)\end{array}$ & 1.55 & 0.42 & 0.27 & 0.30 & 1.40 \\
\hline $\begin{array}{l}\text { Sacramento, } \\
\text { CA }\end{array}$ & (S91) & $\begin{array}{l}\text { Suburban } \\
\text { residential }\end{array}$ & Aug 1991 & $\begin{array}{l}\text { Grimmond } \\
\text { et al. } \\
\text { (1993) }\end{array}$ & 1.26 & 0.41 & 0.33 & 0.26 & 1.61 \\
\hline Chicago, IL & (C95) & $\begin{array}{l}\text { Suburban } \\
\text { residential }\end{array}$ & $\begin{array}{l}\text { Jun/Aug } \\
1995\end{array}$ & $\begin{array}{l}\text { King and } \\
\text { Grim- } \\
\text { mond } \\
(1997)\end{array}$ & 1.24 & 0.46 & 0.37 & 0.17 & 2.69 \\
\hline Chicago, IL & (C92) & $\begin{array}{l}\text { Suburban } \\
\text { residential }\end{array}$ & Jul 1992 & $\begin{array}{l}\text { Grimmond } \\
\text { et al. } \\
\text { (1994) }\end{array}$ & 0.87 & 0.32 & 0.38 & 0.30 & - \\
\hline
\end{tabular}

The comparison is limited to summer measurements using the eddy-covariance technique in residential sites. Ratios are the same as those defined in Table 4

\subsubsection{Bowen Ratio}

It is important to consider the relative partitioning of the turbulent convective fluxes, the Bowen ratio $\left(\beta=\frac{Q_{H}}{Q_{E}}\right)$. Figure 5 shows the variability of $\beta$ through the day for the cloudy and near clear-sky conditions. It should be noted that $\beta$ is often poorly determined when fluxes are small, as is common at night and during sunrise and sunset transition periods; hence nocturnal $\beta$ is not plotted. $\beta$ appears to follow the trend of $\Delta Q_{S}$ (Fig. 5). The mean daytime $\beta$ values are $0.46,0.48$ and 0.47 respectively for the cloudy, near clear-sky and all-sky conditions; also the mean daily values are $0.39,0.44$ and 0.41 respectively (Table 4$)$. The influence of water availability from the frequent grass irrigation and rainfall during the measurement 

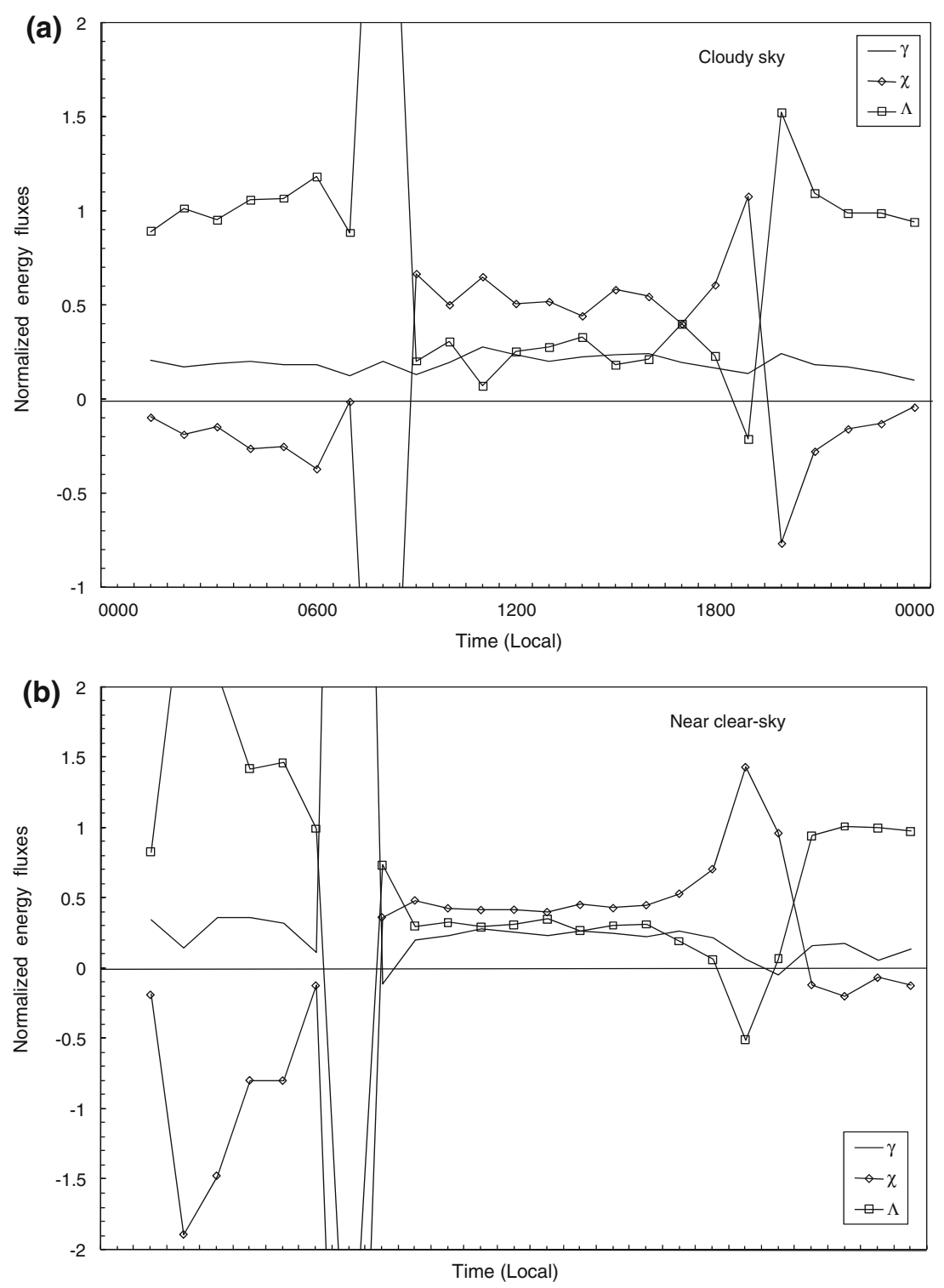

Fig. 6 Ensemble hourly-averaged normalized energy fluxes, sensible heat $(\gamma)$, latent heat $(\chi)$, and storage heat $(\Lambda)$ for cloudy $(\mathbf{a})$ and near clear (b) sky conditions

period is obvious here. The daytime Bowen ratio values are larger than their daily values for all-sky conditions, but the $\beta$ values are about $12-15 \%$ smaller under cloudy sky conditions than near clear-sky conditions, indicating the increase of $Q_{H}$ under near clear-sky conditions discussed in Sects. 3.3.1 and 3.3.2. These $\beta$ values are much lower than those reported for typical North American suburban areas during summer (Table 5). Grimmond and Oke (1995) in their Table 4 reported $\beta$ values of $0.88,0.94,1.29$ and 1.54 for Chicago, Sacramento, Los Angeles and Tucson, respectively under daytime cloudy sky conditions. The corresponding values for clear-sky conditions are $0.78,1.37,1.40$ and 1.83 for Chicago, Sacramento, 
Los Angeles and Tucson, respectively. The closest to values obtained in this study is Chicago with an all-sky daytime value of 0.87 and daily value of 0.71 (Grimmond and Oke 1995; Table 5). The Greenwood $\beta$ values are also the lowest compared to summer values reported for other urban and suburban locations around the world, such as Edinburgh, Scotland; Basel, Switzerland; Marseille, France; Christchurch, New Zealand; Tokyo, Japan and Ouagadougou, Burkina Faso (Nemitz et al. 2002; Christen and Vogt 2004; Grimmond et al. 2004b; Spronken-Smith 2002; Moriwaki and Kanda 2004; Offerle et al. 2005a,b).

\section{Storage Heat Flux}

The absolute values, diurnal behaviour, and the fraction of the net radiation partitioned into the storage heat flux, $\Delta Q_{S}\left(\Lambda=\frac{\Delta Q_{s}}{R n}\right)$ in our exurban Greenwood site (Table 4) were similar to those observed in other cities, and nearly identical to those observed in suburbs of Chicago and Miami (Table 5). In both of those cities, $\Delta Q_{S}$ peaks at about $200 \mathrm{~W} \mathrm{~m}^{-2}$ shortly before solar noon, decreases to its daily minimum near sunset, recovers somewhat by midnight, thereafter remaining fairly constant until sunrise (Grimmond and Oke 1995; Newton et al. 2007). The main difference between the $\Delta Q_{S}$ of these two suburban sites and our exurban location was the timing of maxima and minima. Unlike Chicago and Miami, $\Delta Q_{S}$ at Greenwood peaked 1 and $2 \mathrm{~h}$ after noon for near clear and cloudy conditions respectively, fell to its daily minimum, and then rose slightly again near sunset, remaining fairly constant thereafter until sunrise. A lag of $1 \mathrm{~h}$ is noted for peaks and the minimum under near clear and cloudy conditions and the negative nocturnal $\Delta Q_{S}$ values are similar at the three sites (approximately $-50 \mathrm{~W} \mathrm{~m}^{-2}$ ), see Fig. 5. The mean daytime $\Lambda$ is also remarkably similar in Chicago, Miami, and Greenwood (0.30, 0.30 and 0.29) respectively, and are near the upper end of the observed range of suburban values (Table 5). It is not particularly surprising that heat storage plays a large role in the energy budget of exurban Greenwood given the ample amount of moisture present in the soil, vegetation, and air to promote efficient absorption of heat and provide a large heat capacity.

The diurnal variation of $\Lambda$ in Greenwood, Kansas City is also essentially similar to that observed in suburban residential areas of Chicago, Los Angeles, Sacramento and Miami (Grimmond and Oke 1995; Newton et al. 2007) and the steady daytime decrease from approximately 0.5 near sunrise to zero at sunset is present in all cases (Fig. 6b). However, this daytime decrease is not steady under cloudy conditions in Greenwood, Kansas City (Fig. 6a); the trend is due to the pattern of hysteresis between $\Delta Q_{S}$ and $R_{n}$ (Fig. 7). Under cloudy conditions available energy is reduced and so is the ability of the urban fabric to absorb energy into $\Delta Q_{S}$ due to shading by the clouds. Hence, unlike for clear-sky conditions where $\Delta Q_{S}$ absorbs more energy in the early part of the day, more energy may actually be absorbed in the latter part of the day when skies become clear (Fig. 7). The pattern is also the mirror image of the dominant convective latent heat flux $Q_{E}$ (Fig.6) reflecting the daily variation in heat exchange between conduction and convection, while the fraction used by sensible heating remains fairly constant (Fig. 6). This trend has also been observed in other cities when $Q_{H}$ is the dominant convective flux (Grimmond and Oke 1995; Newton et al. 2007). At night, as in most other cities, $\Lambda$ has the fairly constant value of unity; i.e. the net radiation loss is matched almost entirely by the removal of heat from storage (Fig. 5). The 'excess' removal of stored sensible heat from storage is partitioned into nocturnal evapotranspiration $\left(Q_{E}\right)$. The ratio of the sensible heat flux to the atmosphere and that stored in the suburban fabric $\left(\kappa=\frac{Q_{H}}{\Delta Q_{s}}\right)$ is a measure of the partitioning of the sensible heat fluxes between the air and 

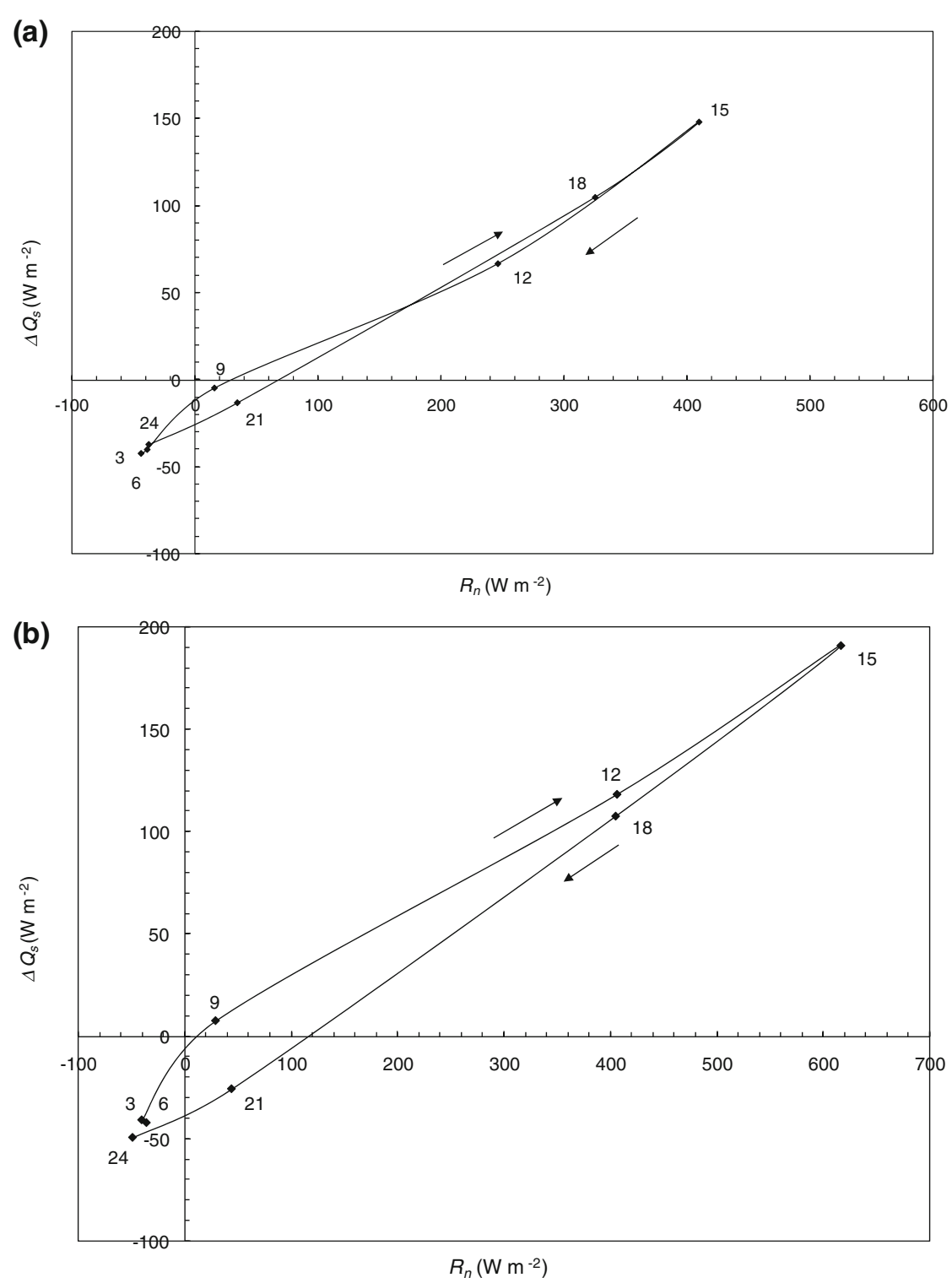

Fig. 7 Mean diurnal hysteresis pattern between heat storage flux $\left(\Delta Q_{s}\right)$ and net radiation $\left(R_{n}\right)$ for cloudy (a) and near clear (b) sky conditions. Values next to points show the hour of day

the surface. When $\kappa$ is greater than unity, the atmosphere dissipates a greater portion of the radiant energy than is stored; when it is less than unity the surface is a more effective sink (Grimmond and Oke 1999b; Newton et al. 2007). The daytime ratios of $\kappa$ are more than $40 \%$ lower than their daily fractions for all-sky conditions (Table 4). This indicates that, during the daytime, $\Delta Q_{s}$ is an effective sink of the net radiant energy, whereas on a daily basis, the atmosphere dissipates a greater portion of the available energy than is stored. Table 5 also shows that the Kansas City values are the lowest compared to other suburban sites, where $\kappa$ 
is greater than unity. Because errors, including measurement uncertainties in the fluxes and unmeasured effects such as advection, accumulate in $\Delta Q_{s}$, comparisons of the storage term across sites should be interpreted with caution. However, the relative similarity between the magnitudes and diurnal patterns of $\Delta Q_{s}$ between our exurban site and suburban sites leads us to conclude that $\Delta Q_{s}$ is relatively similar, whereas the difference in $\kappa$ mainly reflects the more rural, low Bowen ratio characteristic of our exurban site.

\section{Conclusions}

This study reports the first measurements of the surface energy balance at Greenwood, near Kansas City, Missouri, a site representative of the newly developed exurban land-use types that have been rapidly expanding in the mid-continental U.S.A. Energy partitioning was dominated by latent heat under both cloudy and near clear-sky conditions, The mean daytime Bowen ratio $(\beta$ ) values are $0.46,0.48$ and 0.47 respectively for the cloudy, near clear-sky and all-sky conditions; also the mean daily values are $0.39,0.44$ and 0.41 respectively. Net radiation $\left(R_{n}\right)$ increased rapidly from dawn $\left(-34\right.$ and $\left.-58 \mathrm{~W} \mathrm{~m}^{-2}\right)$ during the night to reach a maximum (423 and $630 \mathrm{~W} \mathrm{~m}^{-2}$ ) after midday for cloudy and near clear-sky conditions respectively. Mean daytime values are 254 and $370 \mathrm{~W} \mathrm{~m}^{-2}$, respectively for the cloudy and near clear-sky conditions, while mean daily values are 114 for cloudy and $171 \mathrm{~W} \mathrm{~m}^{-2}$ for near clear-sky conditions, respectively. The corresponding values are 312 and $143 \mathrm{~W} \mathrm{~m}^{-2}$ for all clear-sky conditions. Midday surface albedo values were 0.25 and 0.24 for the cloudy and near clear-sky conditions, respectively. The albedo exhibited an angular dependence on the solar elevation of the sun contrary to earlier observations over urban and suburban areas, but similar to vegetated surfaces. The latent heat flux $\left(Q_{E}\right)$, sensible heat flux $\left(Q_{H}\right)$ and the residual $\Delta Q_{s}$ terms accounted for between $46-58 \%, 21-23 \%$ and $18-31 \%$ of $R_{n}$ for all-sky conditions and time averages respectively. These observed albedo, $R_{n}$ and $Q_{E}$ values are higher than the values reported for suburban areas with high summer evapotranspiration rates in North America. The results suggest that the rapidly growing residential areas at the exurban fringe of large metropolitan areas have a surface energy balance that is more similar to the rural areas from which they were developed than it is to the older suburbs and city centres that make up the urban fabric to which they are being joined. Further studies are required to determine how the characteristics of these exurban areas will change with further modifications to the land cover and the growth of the tree canopy over time.

Acknowledgements This project was partly funded by the University of Missouri Research Board Grant \#KA096. We are grateful for the assistance of Mr. Chris Price and Mr. Lee Kump, owners of the properties on which we sited the telescoping mast and measurement platform. The technical support of Mr. Bert Isaacks and Lee Ward is also greatly appreciated.

Open Access This article is distributed under the terms of the Creative Commons Attribution Noncommercial License which permits any noncommercial use, distribution, and reproduction in any medium, provided the original author(s) and source are credited.

\section{References}

Adegoke JO, Pielke R, Carlton AM (2007) Observational and modeling studies of the impacts of agriculturerelated land use change on planetary boundary layer processes in the central US. Agric For Meteorol 142:203-215

Allen SJ, Wallace JH, Gash JHC (1994) Measurements of surface albedo over natural vegetation in the sahel. Int J Climatol 14:625-636 
Carleton AM, Travis DJ, Adegoke JO, Arnold DL, Curran S (2008) Synoptic circulation and land surface influences on convection in the Midwest US "Corn belt" during the summers of 1999 and 2000. Part II: role of vegetation boundaries. J Clim 21:3617-3641

Christen A, Vogt A (2004) Energy and radiation balance of a central European city. Int J Climatol 24: 1395-1421. doi:10.1002/joc. 1074

Dabberdt WF, Carroll MA, Baumgardner D, Carmichael G, Cohen R, Dye T, Ellis J, Grell G, Grimmond S, Hanna S, Irwin J, Lamb B, Madronich S, McQueen J, Meagher J, Odman T, Pleim J, Schmid HP, Westphal DL (2004) Meteorological research needs for improved air quality forecasting: report of the 11th prospectus development team of the US Weather Research Program. Bull Am Meteorol Soc 85: 563-586

Finkelstein PL, Sims PF (2001) Sampling error in eddy correlation flux measurements. J Geophys Res 106(D4):3503-3509

Foken T, Wichura B (1996) Tools for quality assessment of surface-based flux measurements. Agric For Meteorol 78:83-105

Foken T, Göckede M, Mauder M, Mahrt L, Amiro BD, Munger JW (2004) Post-field data quality control. In: Lee X (ed.) Handbook of micrometeorology: a guide for surface flux measurements. Kluwer, Dordrecht, pp 181-207

Grimmond CSB (1992) The suburban energy-balance: methodological considerations and results for a midlatitude west-coast city under winter and spring conditions. Int J Climatol 12:481-497

Grimmond CSB, Oke TR (1995) Comparison of heat fluxes from summertime observations in the suburbs of four North American cities. J Appl Meteorol 34:873-889

Grimmond CSB, Oke TR (1999a) Aerodynamic properties of urban areas derived, from analysis of surface form. J Appl Meteorol 34:873-889

Grimmond CSB, Oke TR (1999b) Heat storage in urban areas: local-scale observations and evaluation of a simple model. J Appl Meteorol 38:922-940

Grimmond CSB, Oke TR (1999c) Evapotranspiration rates in urban areas. Impacts of urban growth on surface water and groundwater quality. In: Proceedings of IUGG99 symposium HSS, Birmingham, 19-24 July, 1999. IAHS Publication no. 259

Grimmond CSB, Oke TR (2002) Turbulent heat fluxes in urban areas: observations and a local-scale urban meteorological parameterization scheme (LUMPS). J Appl Meteorol 41:792-810

Grimmond CSB, Oke TR, Cleugh HA (1993) The role of "rural" in comparisons of observed suburban-rural flux differences. In: Porceedings of the Yokohama Symposium, exchange processes at the land surface for a range of space and time scales, vol 212, July 1993. IAHS Publication, pp 165-174

Grimmond CSB, Souch C, Grant RH, Heisler G (1994) Local scale energy and water exchanges in a Chicago neighborhood. Chicago's urban forest ecosystem: results of the Chicago urban forest climate project. USDA Forest Service Northeastern Forest Experiment Station, General Technical Report NE-186,46-70.http://www.fs.fed.us/ne/newtown_square/publications/technical_reports/pdfs/scanned/ OCR/gtr186index.htm or from Northeastern Forest Experiment Station, 5 Radnor Corporate Center, 100 Matsouford Rd., Suite 200, P.O. Box 6775, Radnor, PA 19087-4585. Accessed 15 Dec 2008

Grimmond CSB, Souch C, Hubble M (1996) The influence of tree cover on summertime energy balance fluxes, San Gabriel Valley, Los Angeles. Clim Res 6:45-57

Grimmond CSB, Su HB, Offerle B, Crawford B, Scott S, Zhong S, Clements C (2004a) Variability of sensible heat fluxes in a suburban area of Oklahoma City. The joint between 8th symposium on integrated observing and assimilation systems in the atmosphere, oceans and land surface and the symposium on planning, nowcasting, and forecasting in the urban zone, Seattle, Washington, American Meteorological Society. http://ams.confex.com/ams/pdfpapers/67542.pdf. Accessed 15 Dec 2008

Grimmond CSB, Salmond JA, Oke TR, Offerl B, Lemonsu A (2004b) Flux and turbulence measurements at a densely built-up site in Marseille: heat, mass (water and carbon dioxide), and momentum. J Geophys Res 109:D24101. doi:10.1029/2004JD004936

King T, Grimmond S (1997) Transfer mechanisms over an urban surface for water vapour, sensible heat, and momentum. Preprints. In: 12th Symposium on boundary layers and turbulence, Vancouver, BC, Canada. Am Meteorol Soc 455-456

Lenschow DH, Mann J, Kristensen L (1994) How long is long enough when measuring fluxes and other turbulent statistics? J Atmos Ocean Technol 11:661-673

Liebethal C, Foken T (2003) On the significance of the Webb correction to fluxes. Boundary-Layer Meteorol 109:99-106

Mann J, Lenschow DH (1994) Errors in airborne flux measurements. J Geophys Res 99(D7):14519-14526

Mauder M, Foken T (2004) Documentation and instruction manual of the eddy covariance software package TK2. Universität Bayreuth Arbeitsergebnisse Nr. 26, Bayreuth, December 2004, 45 pp 
Meehl GA, Tebaldi C (2004) More intense, more frequent, and longer lasting heat waves in the 21st century. Science 305:994-997

Mestayer P et al. (2004) The urban boundary layer field campaign in Marseille (UBL/CLU-ESCOMPTE): set-up and first results. Boundary-Layer Meteorol 114:315-365

Moffat AM, Papale D, Reichstein M, Hollinger DY, Richardson AD, Barr AG, Beckstein C, Braswell BH, Churkina G, Desai AR, Falge E, Gove JH, Heimann M, Hui DF, Jarvis AJ, Kattge J, Noormets A, Stauch VJ (2007) Comprehensive comparison of gap-filling techniques for eddy covariance net carbon fluxes. Agric For Meteorol 147:209-232

Moore CJ (1986) Frequency response corrections for eddy correlation systems. Boundary-Layer Meteorol 37:17-35

Moriwaki R, Kanda M (2004) Seasonal and diurnal fluxes of radiation, heat, water vapour and CO2 over a suburban area. J Appl Meteorol 43:1700-1710

National Climatic Data Center (2004) Climatography of the United States: 1971-2000 climatic normals. National Climatic Data Center, Asheville

Nemitz E, Hargreaves KJ, McDonald AG, Dorsey JR, Fowler D (2002) Meteorological measurements of the urban heat budget and CO2 emissions on a city scale. Environ Sci Technol 36:3139-3146

Newton T (1999) Energy balance fluxes in a subtropical city: Miami FL, MS thesis, Department of Geography, University of British Columbia, Vancouver, BC, Canada, $140 \mathrm{pp}$

Newton T, Oke TR, Grimmond CSB, Roth M (2007) The suburban energy balance in Miami, Florida. Geogr Ann 89:331-347

Offerle B, Grimmond CSB, Oke TR (2003) Parameterization of net all-wave radiation for urban areas. J Appl Meteorol 42:1157-1173

Offerle B, Grimmond CSB, Fortuniak K (2005a) Heat storage and anthropogenic heat flux in relation to the energy balance of a central European city centre. Int J Climatol 25:1405-1419

Offerle B, Jonsson P, Eliasson I, Grimmond CSB (2005b) Urban modification of the surface energy balance in the west African Sahel: Ouagadougou, Burkina Faso. J Clim 18:3983-3995

Oke TR (1987) Boundary layer climates, 2nd edn. Routledge, London, 435 pp

Oke TR (1997) Urban environments. In: Bailey WG, Oke TR, Rouse WRThe surface climates of Canada. McGill/Queens University Press, Montreal, pp 303-327

Oke TR (2004) Initial guidance to obtain representative meteorological observations at urban sites. WMO Instruments and Observing Methods Report No. 81, WMO/TD No. 1250, 51 pp

Oke TR, Spronken-Smith RA, Jauregui E, Grimmond CSB (1999) The energy balance of central Mexico City during the dry season. Atmos Environ 33:3919-3930

Rabin RM, Stadler S, Wetzel PJ, Stensrud DJ, Gregory M (1990) Observed effects of landscape variability on convective clouds. Bull Am Meteorol Soc 71:272-280

Raupach MR, Antonia RA, Rajagopalan S (1991) Rough-wall turbulent boundary layers. Appl Mech Rev 44: $1-25$

Robert SM, Oke TR, Grimmond CSB, Voogt JA (2006) Comparison of four methods to estimate urban heat storage. J Appl Meteorol Climatol 45:1766-1781

Rotach MW, Vogt R, Bernhofer C, Batchvarova E, Christen E, Clappier A, Feddersen A, Gryning B, Martucci SE, Mayer G, Mitev H, Oke TR, Parlow E, Richner H, Roth M, Roulet YA, Ruffieux D, Salmond JA, Schatzmann M, Voogt JA (2005) BUBBLE_an urban boundary layer meteorology project. Theor Appl Climatol 81:231-261

Roth M (2000) Review of atmospheric turbulence over cities. Q J Roy Meteorol Soc 126:941-990

Roth M, Oke TR (1993) Turbulent transfer relationships over an urban surface. I: spectral characteristics. Q J Roy Meteorol Soc 119:1071-1104

Roth M, Oke TR (1994) Comparison of modeled and "measured" heat storage in suburban terrain. Beitr Phys Atmos 67:149-156

Sailor DJ, Lu L (2004) A top-down methodology for developing diurnal and seasonal anthropogenic heating profiles for urban areas. Atmos Environ 38:2737-2748

Schmid HP (1994) Source areas for scalars and scalar fluxes. Boundary-Layer Meteorol 67:293-318

Schmid HP (1997) Experimental design for flux measurements: matching scales of observations and fluxes. Agric For Meteorol 87:179-200

Schotanus P, Nieuwstadt FTM, De Bruin HAR (1983) Temperature measurement with a sonic anemometer and its application to heat and moisture fluctuations. Boundary-Layer Meteorol 26:81-93

Spronken-Smith RA (2002) Comparison of summer- and winter-time suburban energy fluxes in Christchurch, New Zealand. Int J Climatol 22: 979-992. doi:10.1002/joc.767

Steyn DG (1985) An objective method to achieve closure of over determined surface energy budgets. Boundary-Layer Meteorol 33:303-311 
Stott PA, Stone DA, Allen MR (2004) Human contribution to the European heatwave of 2003. Nature 432: 610-613

Tanner BD, Swiatek E, Greene JP (1993) Density fluctuations and use of the krypton hygrometer in surface flux measurements. In: Allen RG (ed.) Management of irrigation and drainage systems: integrated perspectives. American Society of Civil Engineers, New York, pp 945-952

Van Dijk A, Kohsiek W, De Bruin HAR (2003) Oxygen sensitivity of krypton and Lyman-alpha hygrometers. J Atmos Ocean Technol 20:143-151

Vickers D, Mahrt L (1997) Quality control and flux sampling problems for tower and aircraft data. J Atmos Ocean Technol 14:512-526

Webb EK, Pearman GI, Leuning R (1980) Correction of the flux measurements for density effects due to heat and water vapour transfer. Q J Roy Meteorol Soc 106:85-100

Wilczak JM, Oncley SP, Stage SA (2001) Sonic anemometer tilt correction algorithms. Boundary-Layer Meteorol 99:127-150 